DOI 10.37882/2223-2982.2021.02.16

\title{
ПРЕДСТАВИТЕЛИ КОРЕЙСКОЙ ДИАСПОРЫ НА УРАЛЕ: БИОГРАФИЯ КАН ДИН ХО (1903-1937 ГГ.)- БОРЦА ЗА НЕЗАВИСИМОСТЬ КОРЕИ ${ }^{1}$
}

\section{REPRESENTATIVES OF THE KOREAN DIASPORA IN THE URALS: BIOGRAPHY OF KANG JIN HO (1903-1937) - KOREAN INDEPENDENCE FIGHTER ${ }^{2}$}

\section{Lim Sungjae \\ I. Musinova}

Summary: There are a significant number of researches devoted to the Russian Koreans and their contribution to the Korea Independence Movement both the Republic of Korea and in the Russian Federation, but, unfortunately, the activities of Korean patriots and anti-Japanese activists who lived in the Urals are still poorly examined. This article attempts to provide information about Kang Jin Ho, a representative of the Korean diaspora in Sverdlovsk (Yekaterinburg) in the late 1920s - 1930s and his participation in the Korean Independence movement.

Keywords: Korea, USSR, History of the Korean diaspora in Russia, Korean diaspora in the Urals, Kang Jin Ho.
$\mathrm{B}$ Российской Федерации и в странах СНГ, а также в Республике Корея существует обширная литература, посвященная истории советских и российских корейцев, при этом, к сожалению, все еще слабо исследована группа корейцев, проживавших на Урале, особенно их вклад в развитие антиимпериалистического, антияпонского патриотического движения в первой половине XX в. [4, с. 46-47] Между тем, среди них было немало ярких и интересных людей, которые активно принимали участие в событиях той эпохи. Осуществляя деятельность в интересах корейского народа, они нередко параллельно вносили вклад и в развитие советского государства [7, с. 9-10].

После аннексии Корейского полуострова Японией в 1910 г. в стране и за ее пределами начало активно формироваться антияпонское движение. Корейцы, проживавшие на территории России, также приняли в нем активное участие [8, с. 30-31]. Антияпонское движение набирало обороты и на территории нынешней России в таких крупных центрах как Петербург и Москва, в го-
Лим Сунгжае,

Преподаватель, Уральский федеральный университет им. Первого президента РФ Б.Н. Ельцина aluminary@gmail.com

Мусинова Ирина Александровна старший преподаватель, Уральский федеральный университет им. Первого президента РФ Б.Н. Ельцина irina.musinova@gmail.com

Аннотация: В Российской Федерации и в странах СНГ, а также в Республике Корея существует обширная литература, посвященная истории советских и российских корейцев, при этом, к сожалению, все еще слабо исследована история корейцев, проживавших на Урале. Особенно мало исследован их вклад в развитие антиимпериалистического, антияпонского патриотического движения. В настоящей статье предпринята попытка представить информацию о Кан Дин Хо-представителе корейской диаспоры г. Свердловска (Екатеринбурга) конца 1920-х- 1930-х гг.

Ключевые слова: история корейской диаспоры в России, корейцы России и стран СНГ, корейцы Урала, Кан Дин Хо.

родах Сибири вдоль Транссибирской железной дороги, и, в особенности, на Дальнем Восток [6, 13-14]. Поддерживали патриотические настроения и представители корейской диаспоры на Урале. В настоящей статье будет представлена информация о представителе корейской диаспоры г. Свердловска (Екатеринбурга) 1920-1930-х гг. Кан Дин Хо (кор. Кан Чжинхо, 강진호).

Кан Дин Хо родился во Владивостоке 25 августа 1903 г. в семье корейского крестьянина-арендатора, детские годы провел в Приморье вместе с матерью и двумя братьями: Кан Хи Сен (впоследствии проживал на станции Кедровка Приморского края, являлся колхозником) и Кан Ён Су (занимался рыболовством, в 1934 г. перешел на территорию Кореи). Третий, самый старший брат Кан Дон Хо, был партизаном в Хабаровске, подробных сведений в биографии о нем не сохранилось [9, л. 1-2].

Начальное образование Кан Дин Хо получил на территории Приморья в 1921-1924 гг., а затем в 1925 гг. продолжил обучение в Манчжурии, в ее Северо-Восточной

1 Исследование выполнено за счет гранта Российского фонда фундаментальных исследований (РФФИ) (проект о 19-5951004/19 от 15.01.2020)

2 This work was supported by the Russian Foundation for Basic Research, grant number 19-59-51004/19 
части, примыкавшей непосредственно к Корейскому полуострову и Приморью и получившей название «Кандо», кор. 간도). Обучался он в городе Лунцзин (кор. 용정, упрощ. кит. 龙井) в корейской средней школе «нового типа». По словам Кан Дин Хо, до 1924 г. во Владивостоке продолжать образование было для него затруднительно, поэтому он направился в Северо-Восточную Манчжурию. Обучался Кан Дин Хо в школе Тайдун (кор. «Тэсон», 대성학교), что примечательно, в ней в то же время учился знаменитый корейский поэт-патриот Юн Дончжу (кор. 윤동주). Школа была основана в 1921 г., по типу относилась кт.н. «народным школам» («минджокчунхаккё», кор. 민족중학교). Один год обучения оплачивала семья Кан Дин Хо, а последующие три года он учился бесплатно (обучение оплачивало корейское антияпонское национальное общество).

В найденных 24 апреля 1937 г. при обыске в квартире Кан Дин Хо двух тетрадях с записями на корейском языке («хангыле») и ханмуне содержится информация, при анализе которой видно, что он направился в регион не случайно, а школа финансировалась за счет организаций корейских патриотов-националистов.

Еще с 1910-х гг. в городе Лунцзин (кор. 용정, упрощ. кит. 龙井), расположенном в современной провинции Гирин, проживала значительная корейская диаспора. Еще в 1860- 1880-х гг. в этом районе как легально, так и нелегально проживало значительное количество корейского населения, особенно много людей прибыло из северной части Корейского полуострова. Это было связано с неурожаями, занятиями охотой, торговлей, работой в шахтах и на строительстве, а также наличием большого количества свободных земель. При этом налоги, составлявшие часть урожая, были гораздо ниже, чем в Чосон. Количество корейского населения в регионе значительно увеличилось после аннексии Кореи Японией в 1910 г.: в регион прибыло большое количество недовольных японским колониальным режимом, создававались вооруженные антияпонские партизанские отряды «ыйбён» [4, с. 19-20].

Город также известен событиями 13 марта 1919 г. (кор. 북간도 3.13 반일 운동), когда узнавшие о Первомартовском движении корейские студенты и жители города Лунцзин провели масштабную антияпонскую акцию с требованием предоставить Корее независимость. В антияпонских протестах приняло участие более 10 тыс. человек. Японская полиция открыла стрельбу по участникам мирного протеста, в результате 17 участников акции мирного протеста были убиты на месте, несколько тысяч человек были арестованы.

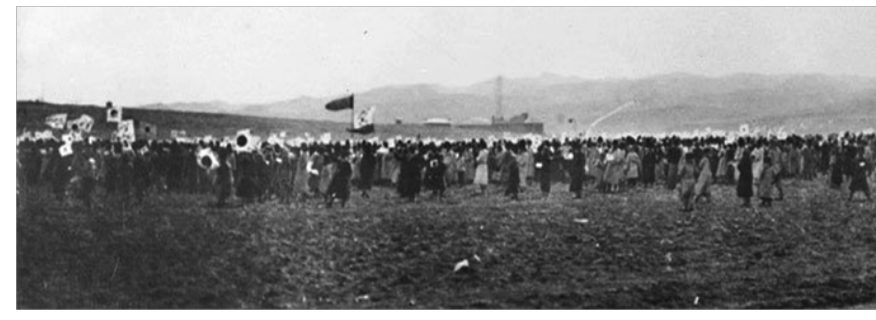

Антияпонская акция протеста 13 марта 1919 г. в г. Лунцзин (서전 벌) Источник:

В 1920-е гг. небольшой городок стал образовательным центром для корейцев, где учащиеся составляли около 40\% населения и являлись одной из наиболее активных и просвещенных групп. Всего в городе существовало рекордное количество корейских средних школ шесть: католическая средняя школа Донгхын (кор. 동 흥중학교); созданная английскими миссионерами прояпонская средняя школа Ынджин (кор. 은진중학교); буддийская и более независимая от японского влияния средняя школа Десонг (кор. 대성학교); женская средняя школа Мёнгсин (кор. 명신중학교) и средняя школа Кынхва (кор. 근화중학교) [8, с. 33].

Наличие такого значительного количества корейских учебных заведений было связано с тем, что в 1910-1919 гг. Япония осуществляла в Корее жесткую колониальную политику, связанную с ассимиляцией и подавлением любых проявлений недовольства. Сфера образования являлась ключевой для осуществления такой политики, поэтому японцы препятствовали росту школ любого уровня в Корее, особенно это касалось школ второй и третьей ступени. Вплоть до 1920-х гг. в Корее не было собственного высшего учебного заведения, и многие образованные корейцы обучались в университетах в США и Японии. В результате такой политики в 1910-1920-е гг. серьезной популярностью начали пользоваться частные учебные заведения, в том числе, неофициальные, которые чаще всего создавались либо миссионерами и религиозными организациями, либо представителями корейского националистического движения. Ситуация с отношением японских колониальных властей к образованию в Корее несколько изменилась лишь после Первомартовского движения 1919 г. [3, с. 78]

После окончания школы Кан Дин Хо женился на кореянке Нам Оксун (русское имя Нам Екатерина), дочери корейца Нам Си Ёна, у которого проживал во время обучения. Остался в Лунцзине из-за семейного положения, в 1925-1926 гг. преподавал в средней школе Пачжу (кор. 바주중학교). Стал учителем, так как после окончания средней школы Тайдун (кор. «Тэсон») мог преподавать все предметы, соответствовавшие программе школы первой ступени, владел корейским, китайским, японским, русским и английским языками [9, л. 3-4]. 
Недовольство Кан Дин Хо вызывал тот факт, что в средней школе Пачжу воспитание велось в прояпонском духе, среди учеников активно насаждались японский язык и японские традиции, учебники также были на японском языке. Учащимся внушалось, что корейцы являются частью японской нации, что дальнейшее экономическое развитие страны возможно только под руководством Японии. Те, кто был замечен в поддержании идей корейского национализма, подвергались арестам и пыткам. Все собрания проходили под надзором японских политических жандармов, с их разрешения. Проводником прояпонского образования нередко в той или иной степени являлся и преподавательский состав школ $[9$, л. 4].

Кан Дин Хо, работая в школе Паджу также был вынужден формально следовать этим правилам, но копившееся в нем недовольство привело к тому, что в 1931 г. Кан Дин Хо вернулся в г. Владивосток и начал активно участвовать в просветительской деятельности, участвуя в открытии корейских учебных заведений (в том числе, вечерних школ для рабочих) и газет на корейском языке. Он и сам преподавал в одной из корейских школ, был хорошо знаком с другим корейским учителем-просветителем Ким Чен Хо. Увлекся он и изучением идей марксизма, достижений западной философии и основ политической мысли. В упомянутых ранее тетрадях сохранились подробные конспекты, записанные на ханмуне. О патриотических идеях Кан Дин Хо свидетельствуют дневниковые записи, черновики писем и стихи, оставленные на свободных страницах тетради и на полях $[9$, л. 5].

Создание корейских национальных школ и объединений корейских граждан было реакцией корейских патриотов на попытку японских колониальных властей воспитать из корейцев «лояльных подданых Японской империи», прививать корейцам в рамках школьной программы лишь «простые практические знания, соответствующие нуждам имперской экономики и духу времени» [3, с. 79]. Система школьного образования в Корее колониального периода разительно отличалась от японской, уровень преподаваемых дисциплин и требования к учащимся в Корее были значительно ниже. В тот период существовали школы первой ступени, где обучение длилось всего 3-4 года [3, с. 80], гораздо меньше было школ второй ступени (4 года), и совсем ничтожное количество (менее 20) составляли высшие профессиональные школы, где обучение велось в течение 3-5 лет.

Как известно, антияпонская патриотическая деятельность осуществлялась вооруженным путем (покушения на убийство в отношении деятелей, связанных с японским колониальным режимом, создание вооруженных антияпонских партизанских отрядов «ыйбён»), а также невооруженными методами, включавшими в себя публикацию газет и журналов, просветительскую деятель- ность, создание корейских школ, где велось преподавание корейского языка, истории и литературы, а также сбор сведений и написание обличительных материалов о деятельности японского оккупационного режима [8, c. 18-19].

Именно второй метод избрал для себя Кан Дин Хо, так как к середине 1920-х - началу 1930-х гг. Японии удалось подавить основные очаги корейского вооруженного сопротивления, были арестованы основные борцы за независимость на территории Корейского полуострова, было все меньше возможностей вступать с японцами в открытое вооруженное противостояние.

Во второй половине 1910-х - 1920-е гг. местные корейские лидеры и эмигранты стремились в ответ на колониальную политику создать школы нового образца во Владивостоке и Хабаровске, а также в других крупных корейских населенных пунктах Российской империи, а затем и СССР. Не только дети, но и взрослые корейские рабочие и мелкие ремесленники и торговцы изучали в них не только корейский, русский и английский языки, но также математику, экономику, этику, корейскую историю, философию и другие предметы. Считалось, что «новое образование» (кор. 신사상적 교육), которое получат корейские эмигранты в США, СССР и в других «прогрессивных» странах будут способствовать национальному возрождению корейской нации, появится «воздух перемен», соединивший в себе корейские многовековые традиции и просвещенные идеи стран Запада [1]. Именно таких воззрений придерживался известный корейский теоретик-националист Пак Ынсик. Деньги для таких школ собирались с жителей корейских населенных пунктов, их жертвовали корейские рабочие, трудившиеся в рудниках и на заводах [5, с. 110].

Корейские патриоты писали учебные пособия для таких школ и издавали их на свои деньги, переводили произведения, посвященные корейской истории и культуре, с традиционного китайского письма на хангыль, организовывали спектакли, проводили корейские праздники и конкурсы поэтического мастерства не только для этнических корейцев, но и для всех желающих. Эти процессы усилила проходившая по инициативе Комиссариата по национальной политике СССР «советизация» национальных меньшинств, которые активно включились в советское строительство [2, с. 48].

Эти процессы начали тормозиться после 1927 г., когда состоялся 15 съезд Коммунистической партии СССР и был взят курс на коллективизацию. К 1930 г. Было национализировано около 90\% земель в Приморье, в ответ на эти меры в октябре 1929 - марте 1930 гг. около 50000 корейцев перешли с имуществом и с семьями на территорию Манчжурии, в 1931 г. Произошел Манчжурский инцидент, обострились отношения с Японией, в середи- 
не 1930-х гг. началась политика выселения народов из приграничных территорий вглубь страны, аресты и допросы по подозрению в контр-революционной агитации и шпионской деятельности.

Опасаясь ареста, в 1933 г. Кан Дин Хо переехал в г. Свердловск, начал работать на УЗТМ строгальщиком, где проработал вплоть до своего ареста в 1937 г., а также учился в Кооперативном техникуме советской торговли, в марте 1936 г. получил гражданство СССР. Его жена Нам Оксун обучалась на втором курсе того же торгового техникума, работала в швейной мастерской, у супругов в 1937 г. родилась дочь. В Свердловске Кан Дин Хо также являлся активным участником организации «Союз корейских рабочих», поддерживал тесную связь с представителями корейской диаспоры на Урале [9, л. 11].

В 1937 г. его вызывали в качестве свидетеля по делам нескольких репрессированных корейцев, а 24 апреля
1937 г. в его квартире состоялся обыск, при обыске было обнаружено и изъято две тетради с записями на корейском языке и ханмуне, письма и другие личные вещи. Кан Дин Хо утверждал, что записи принадлежали не ему, а корейцу по имени Кан Чен Сон, с которым он встретился во Владивостоке, они вместе преподавали в корейских школах, а тетради он получил для ознакомления $[9$, л. 12].

16 сентября 1937 г. Кан Дин Хо был арестован по обвинению в осуществлении шпионской деятельности в пользу Японии и расстрелян уже на следующий день $[9$, л. 13]. Его захоронение находится на 12 км Москвовского тракта, где в настоящее время открыт мемориал жертвам политических репрессий. Кан Дин Хо обвинили в том, что в 1925-1926 г. Он являлся официальным сотрудником японского политического управления в пограничных районах (в Кандо), а в середине 1926 г. нелегально перешел на территорию СССР.

\section{ЛИТЕРАТУРА}

1. Park M. Alyssa. Sovereignty Experiment: Korean Migrants and the Building of Boarders in North-East Asia, 1860-1945. Cornell University Press, 2019. - 306 p.

2. Kim Young-Jick. Colonial Rule and Social Change in Korea, 1910-1945.

3. Abe Hiroshi. Higher Learning in Korea under Japanese Rule. Keijo Imperial University and the "People's University" Campaign.

4. 박환. 대륙으로 간 혁명가들. 국학자료원, 2008. [Пак Хван. Тэрюгыро кан хенмёнгадыль/Корейские борцы за независимость Кореи, сражавшиеся на континенте. Сеул: Гукхакчарёвон. 2008]

5. Пак Б.Д. Борьба российских корейцев за независимость Кореи. 1905-1919 гг. М.: ИВ РАН, 2009.

6. 한국독립운동사 강의 (개정판). 한국근현 대사학회, 2007. [Хангуктоннипундонса кан-ый/ Лекции по истории корейского национальноосвободительного движения. Сеул: Хангук кынхёндэса хакхве, 2007]

7. имм Мангём (И.С. Серебряков). - 2 изд., исправ. И доп. - М.: Институт востоковедения РАН, 2007. - 224 с.

8. 권희 영. 한인 사회주의운동 연구. 국학자료 원, 1999. [Квон Хиён. Ханин сахведжу-ый ундон ёнгу/Исследования по истории корейцев-социалистов. Сеул: Гукхвечарёвон, 1999)].

9. Государственный архив административных органов (вердловской области (ГААОСО). Ф. Р-1. Оп. 2. Д. 41775.

(с) Лим Сунгжае (aluminary@gmail.com), Мусинова Ирина Александровна (irina.musinova@gmail.com). Журнал «Современная наука: актуальные проблемы теории и практики» 